\title{
Ewa Jakus-Borkowa, Krystyna Nowik, Nazwy miejscowości w Polsce. Układ a tergo, Wydawnictwo Nowik, Opole 2010, ss. 516
}

Jak informuje tytuł, publikacja Ewy Jakus-Borkowej i Krystyny Nowik jest słownikiem nazw miejscowych w Polsce w układzie a tergo. Słownik ten, jak piszą we wstępie autorki, obejmuje wszystkie współczesne nazwy miejscowe występujące na obszarze Polski, ułożone w porządku alfabetycznym w układzie a tergo, czyli od końca wyrazów. Z wstępu dowiadujemy się, że ,jego bazą materiałową jest komputerowy wykaz urzędowych nazw miejscowości uporząqkowany w kolejności identyfikatorów Głównego Urzędu Statystycznego według stanu z 15 lipca 2004 roku zlokalizowanych zgodnie z obowiązującym obecnie podziałem administracyjnym na szesnaście województw". Autorki informują, że słownik obejmuje nazewnictwo 97202 obiektów zamieszkanych, administracyjnie samodzielnych (miasta i wsie) i niesamodzielnych (części miast, części wsi, osiedla, przysiółki, wybudowania), do których odnosi się 55632 różnych nazw. Są to nazwy jednoczłonowe i wielowyrazowe (struktury proste, zestawienia, wyrażenia przyimkowe i ich kombinacje). Haseł słownikowych jest w omawianym wykazie a tergo około 45 tysięcy, gdyż wiele z nich to hasła zbiorowe, pod którymi zgromadzone są także nazwy zróżnicowane tylko fleksyjnie.

Wartość tego słownika polega przede wszystkim na tym, że jest on dostosowany do specyfiki nazw miejscowych przez to, że poza ojkonimami prostymi, hasła słownikowe stanowią wszystkie składniki nazw wielowyrazowych.

Wielką wartość dla badań nad polską toponimią mają znajdujące się w słowniku informacje dotyczące obszaru występowania ojkonimów z danym leksemem (przez podanie nazwy województwa w skrócie) oraz ich liczby w województwie, a nadto na końcu hasła - ogólnej liczby zawierających go 
nazw na obszarze Polski. Informacje te umożliwiają badania nad geografią występowania leksemów toponimicznych na obszarze Polski oraz nad ich frekwencją na poszczególnych terenach.

Korzystanie ze słownika ułatwiają informacje zamieszczone we wstępie. W obrębie każdego hasła podane są najpierw pojedyncze nazwy z wyrazem hasłowym. Ojkonimy wieloczłonowe przytaczane są oddzielnie. Dla pokazania budowy hasła słownikowego zacytuję punkt $10 \mathrm{z}$ zasad budowy hasła. Autorki informują tam, że „budowa hasła zależy od jakości badanego materiału, zawsze jednak uwzględnia powiązania wyrazu hasłowego z pozostałymi składnikami ojkonimu oraz jego budowę gramatyczna. Aby zasygnalizować te relacje, na- zwy dzielone są na występujące w liczbie pojedynczej i mnogiej oraz porządkowane od form najprostszych do bardziej rozwiniętych". W haśle słownikowym najpierw podawane są nazwy jednowyrazowe, a następnie wymieniane są zestawienia $\mathrm{z}$ wyrazem hasłowym znajdującym się na końcu. Naprzód podawane są zestawienia z przymiotnikami lub liczebnikami, też z rzeczownikami, dalej idą alfabetycznie ułożone zestawienia równoległe, połączone myślnikiem, zaś po nich od nowej linii, pismem prostym nazwy zawierające obok wyrazu hasłowego człon (człony) w przypadku zależnym. Następnie znowu od nowej linii, ale kursywą i w porządku jak wyżej - przytaczane są ojkonimy z wyrazem hasłowym występującym na innym miejscu niż końcowe. Na samym końcu hasła, również podane kursywą, zamieszczone są wyrażenia przyimkowe uszeregowane od prostych do bardziej rozbudowanych.

We wstępie wyróżniono i omówiono kilka rodzajów haseł występujących w słowniku, określonych przez autorki jako hasła: podstawowe, syntetyczne, przywołujące, przyimkowe i rekonstruowane.

Według zamieszczonego we wstępie do słownika sformułowania hasła podstawowe ,gromadzą przede wszystkim jednowyrazowe toponimy ułożone alfabetycznie w szyku «odwróconym». Wyraz hasłowy stanowi cała nazwa [...]. Jeśli jednak wyrazem hasłowym jest ostatni człon nazw kilkuelementowych, to przesuwa się go na pierwsze miejsce, a po dwukropku przytacza się pełną postać ojkonimu".

Według autorek „hasła nazwane syntetycznymi skupiają wszystkie - proste i zestawione - ojkonimy, zawierajace (na różnych pozycjach - jako element ostatni, środkowy lub początkowy) ten sam wyraz hasłowy. Dzięki zgromadzeniu nazw w jednym miejscu te składniki nazw nie umykają uwadze badaczy, a informują o sposobach wykorzystania i atrakcyjności danego leksemu w nazewnictwie geograficznym". Dzięki hasłom syntetycznym zainteresowany łatwo dotrze do pełnego materiału opracowywanego leksemu. Jako przykład może posłużyć hasło Wola, pod którym po nazwie jednoczłonowej na pierwszym miejscu znajdują się wszystkie użycia zebrane z dalszych pozycji 
zestawień nazewniczych. Nie trzeba dodawać, jak cenne są te hasła dla badania leksyki ojkonimów.

Hasłami przywołującymi są człony nazw wielowyrazowych, które nie wystąpiły w żadnej nazwie jako końcowe i tym samym nie zostały umieszczone w indeksie a tergo.

Osobnymi hasłami są przyimki występujące w ojkonimach będących wyrażeniami przyimkowymi.

Specjalnym typem są hasła rekonstruowane z przypadków zależnych. Dotyczą one składników ojkonimów, które nie wystąpiły w mianowniku. Podawane są w nawiasie kwadratowym, np. [Kościuszko]: Dzielnica Kościuszki, Kolonia Kościuszki, Kopiec Kościuszki (3).

Trzeba podkreślić, że toponomaści otrzymali wyjątkowo ważną publikację, dająca nowe perspektywy badawcze. Jest to dzieło nie tylko umożliwiające dokładne opracowanie struktur polskich ojkonimów w odniesieniu do sufiksów, co jest głównym zadaniem słowników a tergo, ale także pozwalające opracować nazwy występujące w postaci zestawień oraz liczbę i formy członów zestawień. Wynika to z dodatkowej pracy włożonej w stworzenie tego dzieła. Różni się ono od słowników a tergo apelatywów, z którymi pokrywają się jego informacje dotyczące haseł podstawowych. Istotne i ważne dla ojkonimów są informacje dotyczące geografii i frekwencji. Opracowanie olbrzymiego zbioru ojkonimów wymagało wielkiego wysiłku autorek. Należy się im wdzięczność ze strony polskich i słowiańskich toponomastów. 